\title{
Twin Research, and its Multiple Births and Expressions: A Short, Personal Voyage Through its Scope, History, and Organization
}

\author{
Paolo Parisi \\ Rome University of Movement Sciences (IUSM), Rome-Foro Italico
}

\begin{abstract}
The he notion of twins and twinning involves a multiplicity of meanings and contexts that altogether encompass an unexpectedly wide and significant part of human experience, culture, and endeavor. This cultural polysemy is, to some extent, also an attribute of twin research, which has structured itself around a multiplicity of scientific areas of enquiry, and across time, throughout a multiplicity of births and rebirths, periodically declining and resurging as a phoenix from its ashes. What is proposed is a short voyage through this polysemy and phoenixity of twinning and twin research, and through the structuring process that has accompanied its developments, international scope, and organization. No claim to completeness, but an attempt to dig into personal memory and experience, and share some recollections of the main steps of the process, and particularly the evolution of the journal, the society, the international meetings, and their role in supporting the area's persistence and continuous revivals and adaptations until today.
\end{abstract}

The Polysemy of Twinning and Twin Research: A Multiplicity of Meanings

Multiplicity is inherent in the word and concept of twinning, which refers to a duplication or multiplication of entities (embryos, as well as crystals, threads, etc.) as indicated by its very root in many languages (two, twain; German zwo, zwei; Russian dva, etc. all from the Latin $d u o$, Greek $d y a$, Sanskit $d v a$, and akin to day, deity, divine, divide). The concept is also culturally polysemic in that it evokes multiple meanings and bears different implications in a variety of contexts, far from restricted to those currently prevalent in a scientific perspective, but rather encompassing a wide diversity of areas of human experience and endeavor, ranging from symbol and myth to culture and society, art and literature, psychoanalysis, medicine, biology.

Uncommon as they are in the human species, twins have a prominent position in human culture.
Twin gods were so widespread in ancient civilisations that the existence of a primordial generalised cult, Dioscurism, from the famous Dioscuri of the GrecoRoman tradition, was suggested by scholars of religion and cultural anthropology (Harris, 1913). Actually, twins appear in creation myths of the most diverse peoples of the world, literate as well as illiterate, and may be seen as an archetype of creation, of the orderly process of divisions through which unity brings about multiplicity; or for that reason as city founders, beginners of a cycle, protectors of new undertakings. And always - somewhat as the androgyne, of which they represent a succeeding determination - they point on the one hand to the harmony and order underlying all creation, and on the other, to the conflict and disorder, opposition and fall which inevitably follow, thereby accounting for the intrinsic ambiguity of creation and the nature of things (Parisi, 1997). Hence the diversity of customs and traditions associated with twins, a universal symbol of duality, killed or banished as devil-like creatures in some cultures, or blessed and adored in many others. It is in fact after them that the ancient Babylonians named the constellation, Gemini, interestingly considered in astrology as that under which all opposition is reabsorbed.

The two quarrelling twins that Alice meets, pointing to opposing directions at a cross-point in Lewis Carroll's Through the Looking-Glass (1871), vividly represent the ambiguity of things and the human mind, of which twins are a living symbol. The twin bond, its conflictual nature, and the intricacies of the twins' individual psychologies and interrelations, are a frequent theme in world literature, and a relevant object of study in developmental psychology (Zazzo,

Received 5 April, 2004; accepted 12 April, 2004.

Address for correspondence: Paolo Parisi, Rome University of Movement Sciences (IUSM), Piazza Lauro De Bosis 15, Rome 00194 Italy. Email:paolo.parisi@iusm.it 
1984, 1986). Conflict is seen as usual by Zazzo, who describes it as Rebecca's syndrome, after the biblical account of Esau and Jacob quarrelling already in their mother's womb; while Shakespeare's Comedy of Errors and Twelfth Night are famous examples of a literary tradition, going back to Plautus's Menaechmi, centered on the humorous ambiguity the twins' identicalness brings about. The strength of the twin bond and the difficulty of breaking it and opening up to a third party are the object of subtle psychological analyses, as in Sand's La Petite Fadette (1849), Mitchell's Gone with the Wind (1926), Wilder's The Bridge of San Luis Rey (1927); and a recurrent theme evokes the mysterious aspects of the deep bonding connecting twins or twin-like couples, from Ruggero and Marfisa in Ariosto's Orlando Furioso (1532) to Urlich and Agatha in Musil's Man without Qualities (1952), while a host of psychic and occult aspects related to twins and doubles can be found in novels such as Dostoevsky's The Double (1846) and countless anecdotal accounts.

From another perspective, descriptive studies of twinning have a long history dating back to ancient texts, and the phenomenon was discussed at length by Hippocrates and the early medical literature (see Gedda, 1951, for a review). Interest was long confined to twinning as such, its occurrence in the various species and situations, and its supposed mechanisms. Detailed studies on its heredity and other determinants were conducted in modern times (e.g., Bulmer, 1959; Dahlberg, 1952; Greulich, 1934; Parisi et al., 1983; Weinberg, 1909; Wyshak \& White, 1965; etc.) and more generally its biology was described (Bulmer, 1970; Gedda, 1951; MacGillivray et al., 1975; Parisi, 1990 ; etc.). Its demography was also documented in various populations, contributing to the understanding of fertility and sterility trends (e.g., Allen \& Parisi, 1990; Eriksson et al., 1976; James, 1972; Parisi \& Caperna, 1982; etc.) and the evolution of reproductive strategies (Allen et al., 1992).

On the other hand, a wide range of studies on the clinical hazards of the twin condition already documented by 19 th century obstetricians (Duncan, $1865)$, produced a wealth of knowledge and clinical improvements in gestation and early postnatal outcome (Keith et al., 1995; MacGillivray et al., 1975). In turn, extensive longitudinal studies helped achieve relevant improvements in twins' growth and a broad understanding of human development and its determinants (Wilson, 1978, 1979), while systematic clinical observations on twins led to far-reaching ideas on the psychology of twins, the couple effect, and related phenomena of more general interest (Zazzo, 1984, 1986).

Of course, twins and twinning have not only been studied per se, but also largely as a tool for the understanding of more general aspects of life and human nature, from the use of twinning as a model in experimental embryology and teratology (Spemann, 1938, summarising much earlier research) contributing to the understanding of developmental biology, to the comparison of differentially exposed twin partners in experimental psychology (Gesell \& Thompson, 1929) and then clinical trials, to the widespread applications of the twin method to human genetic studies and particularly behavior analysis, as will now be described.

\section{The Phoenixity of Twin Research: A Multiplicity of Rebirths}

Coming to what I have called the phoenixity of twin research, what is implied is the fact that multiplicity applies not only to the areas of study related to twins, but also to the life cycles of twin research continuously reborn, as a phoenix rising again from its own ashes.

Scientific interest in the systematic use of twins as a method of enquiry into human nature is known to have been born with Galton's famous paper in 1876. However, this was not followed by additional studies until 1905, when the psychologist Thorndike reported twin resemblances in cognitive tests, and even then, no further developments took place in the short-term. The third, or perhaps the actual birth of the "twin method", which had probably been in the air till then, materialized in 1924 when it had finally become obvious that, contrary to previous beliefs, twins should be differentiated into two kinds. At that time the American psychologist Merriman and the German dermatologist Siemens independently provided an explicit formulation of the method (see Rende et al., 1990). A formulation by Holzinger (1929) shortly after allowed use of twin data for heritability estimates, which immediately became very popular and were for a long time used enthusiastically, with several revisions. Since then, and throughout the 1950s, the twin method was applied to the study of a variety of traits and conditions, especially in psychology and human biology, representing for decades the golden way in human genetics, as highlighted by the thousands of references assembled by Gedda in his monumental book, Studio dei Gemelli, in 1951.

Following World War II, and prompted by illdesigned studies and somewhat simplistic conclusions, as well as by the previous political distortions of twin studies to serve racial discrimination policies, doubts were cast on the basic assumptions of the method (Price, 1950). Faced with increasing criticism, the study of twins was to appear obsolete by the late 1950s, when the emerging cytogenetic and molecular approaches allowed direct genetic analyses in man, overcoming, in the eyes of some, the need for the indirect approaches provided by twins. Although twins continued to be studied in various perspectives, to mainstream human genetics it seemed that twin research had been sentenced to death.

But twin research did not die. A thorough revision of the method's design and its basic assumptions was undertaken, limitations and pitfalls were identified, 
and new approaches and methodologies were developed, until an international symposium in 1969 and a groundbreaking paper (Jinks \& Fulker, 1970) marked a new beginning. A few years later, the First International Congress of Twin Studies (Rome 1974) made it clear that twin research was alive and had begun a new life cycle. This was soon highlighted by innovative methodological contributions, focused on the partitioning of variance components and heredityenvironment interactions and correlations (Eaves et al., 1977, 1978; Fulker, 1978, 1982; Martin et al., 1978; Martin \& Eaves, 1977; etc.) which gave new momentum to the field allowing many successful applications, particularly in the area of behavior genetics and development (Eaves et al., 1989).

At the same time, novel applications were devised (e.g., the half-sib method introduced by Nance, 1976), along with more effective applications of the experimental approach provided by the co-twin method (originally developed by Gesell for research in psychology), in which the comparison of differentially exposed twin partners allows the elucidation of the net effect produced by any given variable: a therapy, a training, a substance, an environment, or any other condition (e.g., Hrubec, 1981). Another powerful approach, involving the study of twins reared apart as classically conducted by Newman et al. (1937), Shields (1962), Juel-Nielsen (1965), was again implemented and meta-analyses (Farber, 1981) and new studies were undertaken.

By stressing its role as a fundamental tool for the study of human complex traits (Nance \& Parisi, 1987), twin research has managed to remain vital in more recent years, when the developments of molecular biology and DNA technologies have become so overwhelming as to threaten the survival of any "classical" approach. Even today, in the post-genomic era, the study of twins maintains a great potential for scientific research in many areas of human biology, psychology, and medicine (Parisi, 1995). It can still provide an ideal approach in behavior and developmental genetics (Plomin et al., 1990), and can contribute greatly to the understanding of many complex conditions, behaviors, and diseases. The chance of combining the classical twin study approach with the most advanced techniques in molecular genetics represents a new outlook for a powerful approach to the genetics of complex traits (Boomsma et al., 2002; Risch \& Zhang, 1995).

\section{The Historical Structuring and Organization of Twin Research: A Multiplicity of Initiatives, and a Personal Journey}

For many years, even though it was widely conducted and seen as the golden way of human genetics, twin research did not have a representative body or association. Prominent research groups developed in several countries, particularly Northern Europe, Germany, the United Kingdom (UK), the United States (US), and others, but there was limited communication among them. Publications were scattered in several areas, ranging from embryology to psychiatry or ophthalmology, and with no specific journal nor meetings, there could hardly be a structuring of the area as such.

Important initiatives took place in Scandinavian countries and elsewhere with the implementation of Twin Registers, and as the newborn science of genetics started to have its journals, some of these, particularly the Acta Genetica et Statistica Medica, founded in 1949 by Gunnar Dahlberg in Sweden, served as an initial forum for twin studies.

A breakthrough occurred in the 1940s, when the Italian doctor Luigi Gedda, having come across an intriguing case of Roman twins (appropriately called Romulus and Remus - Gedda, 1943), developed an interest in the study of twins and decided to start an outpatient department for them at Rome's University Medical Clinic. In the hands of this extraordinary man (for a short biography, see Parisi, 2000), this was to produce, in a matter of just a few years, three initiatives, that together marked the beginning of twin research as an area of investigation of its own.

\section{A Book on Twins}

The first initiative was the publication, in 1951, of a monumental handbook, Studio dei Gemelli ("A Study of Twins"), which assembled, in 1381 pages including some 7000 references, all that was to be found at the time on twins, from antiquity to current publications in all accessible world journals and in the various scientific as well as cultural perspectives. Gedda continued to update the literature for several years on thousands of beautifully handwritten cards and to collect reprints and bind them systematically in some 50 volumes, which turned out to be very instrumental in updating the first part of the work when this was published in the US by Charles C Thomas in 1961.

\section{The Journal}

The second initiative was achieved in parallel and resulted in the foundation, 1 year later (1952), of an international quarterly devoted to twins and medical genetics, Acta Geneticae Medicae et Gemellologiae. A prominent public leader with powerful means and relations, Gedda was able to secure the needed financial support. The first issue appeared in January 1952, elegantly printed by the renowned Vatican Polyglot Press, and was sent to a mailing list of hundreds of scientists and institutions throughout the world. Having entertained correspondence with the leading international scholars in the area while he was writing the book, he could put up an impressive Editorial Board, enlisting some of the founding fathers of the newborn area of study, such as: Bauer, Cummins, Dahlberg, Ford-Walker, Franceschetti, Gesell, Greulich, Hanhart, Kallmann, Kalmus, Kemp, Lamy, Newman, Rife, Siemens, Turpin, von Verschuer, Waardenburg, Wiener, to name but a few. Over the 
years, the Board was enriched by new names, such as Allen, Berg, Christian, Eaves, Eriksson, Fulker, Inouye, Keith, Lejeune, MacGillivray, Nance, Vandenberg, Zazzo, and others.

\section{The Mendel Institute}

The third initiative possibly topped the former two. At the same time as working at his handbook and the journal, Gedda conceived, promoted and himself designed a new medical institution, specifically aimed at meeting the needs of twins while serving twin research and medical genetics. The Gregor Mendel Institute of Medical Genetics and Twin Research, an exceptionally innovative, original and elegant fivestorey building, was officially opened on the 8th of September of 1953, in the presence of the Italian Prime Minister, the Minister of Education, the Cardinal Secretary of State, and many other prominent scientific, religious, and political authorities. The ceremony was preceded by an International Symposium of Medical Genetics, and a special audience and blessing by Pope Pius XII.

A total staff of about 100 doctors, scientists, technicians, and other professionals worked there from the opening, offering free daily assistance in the various medical specialties as well as for psychological and social problems, to any twin pair who applied. Over the years, some 20,000 pairs received regular or occasional assistance of some kind.

\section{The International Action}

The Mendel Institute and the journal rapidly became a reference point for anyone interested in human genetics and twin research. And new initiatives took place at an impressive rate. From the mid 1950s to the early 1960s, Gedda edited and published, in addition to the journal, over 20 monographs, handbooks, or proceedings, and organized the Second International Congress of Human Genetics (Rome 1961), which with its over 1000 participants was to represent a landmark in the historical development of the new discipline, and the starting point of a series of highly successful events. A Permanent Committee for the International Congresses of Human Genetics was established and Gedda was Secretary General for some 20 years.

As I am writing this, 45 years later, I cannot avoid describing things in a personal perspective, as I was part of the story, having just happened to join Gedda and the Mendel Institute in 1959, thus giving rise to an association that was to last over 30 years and see us involved closely together in a variety of initiatives, especially in promoting twin research internationally.

\section{A Twin Institute in Jerusalem}

A fervent believer and a socially and politically committed Catholic since his youth, Gedda lived and expressed his faith through action all of his life.

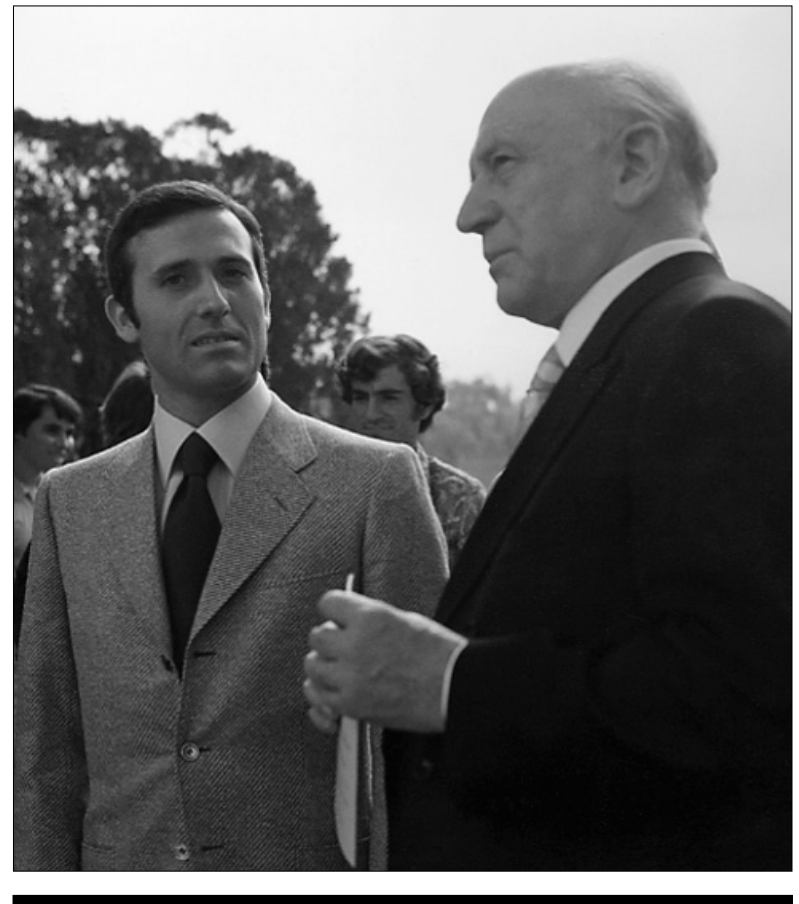

Figure 1

Luigi Gedda (on the right) and Paolo Parisi in Rome, 1971.

Spirituality was his most congenial dimension, and this he also expressed in the establishment of two impressive institutions for meditation retreats, one on the Lago Maggiore and the other in Paestum, both called "Gethsemani", after the garden where Jesus prayed before being arrested.

Eventually, Gedda succeeded in buying a land close to the actual Gethsemani garden, on Mount of Olives in Jerusalem. His idea was to build an institution there which would combine the dimensions he had separately expressed in the Mendel and the Gethsemani Institutes, an institution where faith and science would merge. The idea had been supported by King Hussein, a father of twins and the ruler of Jordan, of which East Jerusalem and Mount of Olives were part at the time, and who helped him acquire the land.

But the territory was then occupied by Israeli forces during the Six-Day War (1967). The land came under military jurisdiction, and because of the extreme sensitivity of its cultural value and landscape, it was made a non-building area and entrusted to the National Parks Authority. As it happened, having volunteered during the war, and thanks to the great support of many Israeli friends, particularly the Mayor of Jerusalem Teddy Kollek, the Director of the Jerusalem Foundation Ruth Cheshin, landscape architect Arye Dvir of the National Parks Authority, the great obstetrician Isaac Halbrecht, and so many others, I could effectively negotiate with the authorities. Eventually, the City Plan was modified, and we could obtain the land back and the permission to build, with an agreement whereby part of the land 
would be developed as an interfaith spiritual park. A cornerstone ceremony took place in 1975 .

By 1980, the first part of the Gedda Institute was completed and an opening ceremony took place at the end of the Third International Congress on Twin Studies. Today, visitors to the Old City standing on the Temple area can admire from close below the beautiful modern building, respectfully integrated into the inspiring landscape of Mount of Olives, its chapel overlooking the very site of the Gethsemani.

\section{The First Congress and the Establishment of the International Society}

As a further attempt to unify twin researchers and counter the decline of interest that had occurred from the late 1950s in the area, an International Symposium was called by Gedda in Rome in 1969, which marked a turning point and the beginning of a new trend (Parisi, 1970). A more systematic action was then undertaken, and on 28 October-2 November 1974, about 200 delegates from 27 countries convened in Rome to attend the First International Congress on Twin Studies.

The Opening was at Rome's Capitol, in the impressive Hall of the Horatii and Curiatii, the famous triplets of Roman mythology. At the Ceremony, marked by the presence of the President of the Italian Republic, the Mayor of Rome, and numerous other officials, LaVona and LaVelda Rowe, ambassadors of the International Twins Association (ITA), gave a short joint speech. At the end, a flagwaving show was offered on Capitol Hill by two Italian twins, who were flag-waving world champions. Twins then played music at the formal banquet served by waiters in 18th century livery in the beautiful Villa Miani on the slopes of Monte Mario hill.

The scientific sessions took place at the National Research Council and covered a variety of areas, from customs and traditions related to twins, to twin biology, growth and development, health and social needs, to multiple pregnancy, twin research in genetics, psychology, medicine, and others. Among those many who were there and were to play a key role in future events, I wish to remember some lifetime friends, with whom I had already, and have later, shared so much, and who were very instrumental and supportive from the very beginning, such as Frank Barron, the great humanistic psychologist from Santa Cruz with whom I shared so much about twin metaphors; Louis Keith, the Chicago obstetrician and a living symbol, with his twin brother Donald, who spoke of the pleasure of being a twin; Marco MilaniComparetti, my elder colleague and Gedda's associate at the Mendel Institute; Ronald S. Wilson, a leading scholar on developmental research, the head of the Louisville Twin Study, and a generous nature; and then of course Gordon Allen, Charles Boklage, Ian A. Böök, P.R.J. Burch, Joe C. Christian, Robert Derom, Aldur W. Eriksson, Ruth Guttman, Joseph Horn, Zed
Hrubec, Warner E. Kloepfer, Fernand Leroy, Adam Matheny, Jean Milner, Walter Nance, René Zazzo, and so many others.

At the closing session, on 2 November in the Mendel Institute's Auditorium, the proposal we made to establish an international association (Gedda \& Parisi, 1974) was unanimously accepted and immediately implemented. A Working Group was appointed, and shortly after the General Assembly of the Congress voted the establishment of an International Society for Twin Studies (ISTS), with the Acta as the official journal, Gedda as President, and myself as Secretary General. It was decided that an international congress would take place every 3 years and that a Business Meeting and new Board elections would take place on that occasion.

For the next 20 years, ISTS was to be run from Rome's central office at the Mendel Institute, while at the same time expanding in scope, scientific weight, and international character and organization, thanks to a regular rotation in the Board and congress venues, and to the continuous endeavor of few of us on both sides of the Atlantic.

Working Groups were established in sensitive research areas, such as Multiple Pregnancy (Ian MacGillivray, Louis Keith, Robert Derom, and others) and Twin Research Methodology (initially Joseph Horn and Joe C. Christian, then Walter Nance, David Fulker, Lindon Eaves, Nick Martin, and others), that were to involve many bright researchers over the years and play a very relevant role. Special emphasis was given to the social and medical problems related to twin care and development, and several mother-of-twin associations and similar bodies joined as Collective Members, represented in the ISTS Board by a Vice President, who was Joyce Maxey, of Iowa, for the first several years. Ronald Wilson with his group in Louisville, Warner Kloepfer of Tulane University, and others, were instrumental and supportive in this respect. The Society had an initial membership of 88 fellows, 51 members, and 7 collective members, representing 23 countries. Its constitution and by-laws were soon approved and the Society was incorporated in Rome. A Newsletter was started in November 1977, with the title, Twins.

\section{The ISTS Congress Series}

At the First Congress Closing Session, Walter Nance proposed that the next congress be held in Indianapolis, where he and Joe C. Christian were Professors at the Department of Medical Genetics, and the invitation was unanimously accepted. A year later, I engaged in a journey across the United States, visiting Indianapolis and many of the groups at the time more active in the field, from New York and Washington to Chicago, Louisville, San Francisco, and more, as well as lecturing at the Behavior 
Genetics Association Meeting in Austin, in order to launch twin research and the new Society.

In my visit to Indianapolis, our colleagues confirmed interest in organising the next congress. As Walter Nance later moved to the Medical College of Virginia in Richmond, he still chaired the Program Committee, but the congress venue was moved to Washington, DC, and Gordon Allen, an epidemiologist of the NIMH well known for his research on twinning, kindly accepted to undertake responsibility for the organization. A man with an extraordinary sense of responsibility and commitment, Allen did so very efficiently, involving other NIH colleagues and twin researchers, such as Zed Hrubec, Manning Feinleib, Ntinos Myrianthopoulos, Ted Schwartz, and others. The Second International Congress on Twin Studies took place at the Washington Capital Hilton on 29 August-1 September 1977, and was another success. At the Business Meeting, Gordon Allen was elected President and the Society accepted Gedda's invitation to host the next congress in Jerusalem on the occasion of the official opening of his new institute on Mount of Olives. The Washington congress greatly helped reviving interest in twin research in the US scientific community, and under Gordon Allen's presidency, ISTS became more structured and better known. An American Publisher, Alan R. Liss of New York, undertook for some years the publication of the journal and of separate congress proceedings, which also gave the area more visibility.

The Third Congress took place in Jerusalem, at the Diplomat Hotel, on 16-20 June 1980, organized by Gedda and Parisi with Ruth Guttman and other Israeli scientists, and was a memorable experience for its more than 200 participants, culminating in the dedication of the Gedda Institute. The scientific program was particularly rich with innovative research and methodological approaches, and made it clear that the season of uncertainties was behind and the area had once more come of age. The Business Meeting elected a leading scholar from Scotland, Ian MacGillivray, Regius Professor of Obstetrics and Gynecology in Aberdeen, an international authority on multiple pregnancy, and a most gentle person and himself father of twins, as new President. At the same time, Luigi Gedda was designated Founding President of the Society.

The Society had expanded, and things went on smoothly from one congress to another, with increasing success, the glue between meetings being ensured by the regular publication of the journal, which ISTS members received as part of their dues, as well as by the Newsletter and the stability provided by the Rome office at the Mendel Institute, where all activities continued to be centralised. In addition, over the years and thanks to the endeavor of committed colleagues such as Walter Nance, Louis Keith, Robert Derom, Nick Martin, and others, the Working Groups became increasingly active and started to have their own specific meetings, particularly in the area of multiple pregnancy (first workshop in Aberdeen in 1979, and then Paris 1982, Malmö 1984, Toulouse 1985, etc.) and of twin research methodology (Workshops in Leuven in 1987, 1989, etc.).

The Fourth Congress took place in London, at the University College, on 28 June-1 July 1983. Under Ian MacGillivray's presidency, the organization was chaired by a leading exponent of the methodological revolution, the geneticist and psychometrician David W. Fulker, with Ronald S. Wilson as Program Committee Chairman and the collaboration of Gerald Corney, of the Galton Laboratory, Elizabeth Bryan and Marian Ellison. The new President was Walter E. Nance, who had meanwhile developed a strong group in human genetics and twin research at the Richmond Medical College, and who, besides chairing the Program Committee of the Washington congress, had also contributed to the organization of the Working Groups, and more generally to the strengthening of the Society, in which he always played a key role.

The Fifth Congress took place in Amsterdam, at the Grand Hotel Krasnopolsky, on 15-19 September 1986. It was hosted by Aldur W. Eriksson, head of the Institute of Human Genetics at the Free University and well known for his demographic studies on twinning in Northern Europe and particularly his beloved home country, the Åland islands and Finland, where he later returned in the mid 1990s. He was assisted lby several members of his staff at the Institute, and by Jacobus F. Orlebeke, head of the Department of Psychology at the Free University, where twin research was to be increasingly developed. Aldur W. Eriksson was then elected President for the following term, 1987-1989.

The Sixth Congress was again held in Rome, 28-31 August 1989, hosted by us as before. The opening was once more in the Capitol and the sessions, which took place at the Ambasciatori Palace Hotel, in Via Veneto, were again rich and intense. The book of abstracts had almost doubled and highlighted the diversity and high level reached by the field. Gedda was at the time 87 years old, but still admirably involved and energetic; he took part in all sessions and presented papers as well as formal talks. At the closing banquet, in the Renaissance Palazzo della Cancelleria at Campo dei Fiori, he offered a parchment scroll to all participants, with an inscription signed by the two of us, as a token of friendship and recognition of the common endeavor that had led us that far.

\section{The Final Years of the Roman Era}

This marked a high point in the history of the Society, as well as the end of the Roman era. Though blessed by nature with an extraordinary health, a powerful mind, and a great will and moral strength, Gedda was getting old, and facing increasing difficulties in finding the needed support to make his many initiatives 
proceed. Even the Mendel Institute's survival was now at stake, and neither he nor I could do much to ease the situation. In a matter of just a couple of years things became worse to the point that a serious local crisis broke out right at the time of the Society's Seventh Congress, which we were eventually both unable to attend. The Congress was held in Tokyo on 22-25 June 1992 under the presidency of Professor Inouye, the noted geneticist and neuroscientist, with the collaboration of Minoru Nakata, Program Chairman, Yoko Imaizumi, and others, and I still regret the blow we inflicted on them with our sudden absence and the news of the Roman crisis, which their good organization and the strength of the Society fortunately was able to absorb. In Tokyo, Lindon Eaves, the brilliant geneticist and mathematician, leader of the methodological innovation, who had just recently moved from Oxford to Richmond, was elected new President.

Though absent in Tokyo, I was still re-elected Secretary General for a seventh 3-year term, but this was my last effort on behalf of ISTS and I had eventually to resign, after preparing the transition at an International Symposium we had in Amsterdam in 1994 to celebrate Aldur Eriksson's retirement. At the Eighth Congress, hosted by Walter Nance in Richmond in 1995, Jaakko Kaprio, the Finnish epidemiologist, undertook responsibility as the new Secretary General of ISTS, and later as host of the Ninth Congress in Helsinki in 1998, while Robert Derom, the Ghent obstetrician, became President. The Presidency then went to Elizabeth Bryan, who hosted the Tenth Congress in London in 2001, and then to Louis Keith and his co-twin Donald, long-standing friends of ISTS who had witnessed and supported it throughout its history, from the very beginnings. At the time of this review, ISTS is about to have its Eleventh Congress in Odense. But all this is really for others to recall, as I have not been an actor, nor even a witness, of ISTS developments since the mid 1990s.

As it happened, in those years, my association with Gedda, which had seen us so closely together for over 3 decades, was coming to an end. Concerned with the future of his initiatives and unable to secure their survival any longer, Gedda decided to donate the Institute to a religious organization. There seemed to be no room to ensure a continuation of the previous lines of activity, which were already fading anyway. While still remaining in contact with Gedda during the following years, I sadly left the Institute. He continued to go there daily, but at some point, and much to his sorrow, this became no longer possible. The Mendel Institute was donated to a Foundation established by the Vatican to administer a renowned hospital in Southern Italy (the "Casa Sollievo della Sofferenza" in San Giovanni Rotondo) originally developed by a great mystic and healer, a Capuchin monk who was recently made a saint, Padre Pio da Pietralcina. The project aim was to transform it into a modern scientific center, and as the Mendel Institute had been conceived and built in the early 1950s, it needed to be entirely restructured. This took several years, during which the Institute had to be closed.

Even then Gedda maintained his endeavor and remained active until the very last, always hoping to see the Institute finished and functioning again. This final dream did not come true, however. Luigi Gedda died in the evening of 26 September 2000, 4 weeks before he would have turned 98 years old, having been born on 23 October 1902. I commemorated him at the Human Genetics Society on 30 November. His wife Linda, who was entirely devoted to him and his only family left, died right before Christmas. Shortly after, on 18 January 2001, a totally restructured Mendel Institute, endowed with modern laboratories, was officially opened and started its new activity as a leading research center in molecular medical genetics, directed by the Foundation's scientific director and leading geneticist, Bruno Dallapiccola. Although still pictured here and there and with their symbol still carved in the Institute's original door handles, twins went back into the shadows.

\section{Again a Revival: From AGMG to Twin Research}

A great asset for the developments that took place in the structuring of twin research for the past 50 years was, from the very beginning, a continuous publication line. Aside from his 1951 monograph and later book series, which being in Italian were not widely known, Gedda founded the Acta in 1952, and edited and published it until 1998, producing a total of some 20,000 pages (I supported him and gradually undertook editorial responsibilities from the mid 1970s, but he continued to oversee the journal in every detail). Initially multilingual, the journal was entirely published in English from the 1970s, which greatly helped its distribution worldwide.

In 1977, following the Washington congress, the journal was for a few years published in New York by Alan R. Liss, adding to its original Latin name the English subtitle, Twin Research. At the same time, the ISTS congress proceedings started being published separately by Liss in his monograph series, Progress in Clinical and Biological Research, and six volumes appeared separately under the same title Twin Research (Gedda et al., 1981; Nance et al., 1978). But the new field was still not strong enough to support such an effort, and the proceedings were later published as part of the journal, which itself came back to Rome from 1983, still keeping the more modern format it had assumed and its English subtitle. Notwithstanding the problems we were already facing at the Mendel Institute, the journal continued to be published regularly and support ISTS activities and the twin research community, ensuring a scientific forum and the needed continuity for several years.

When the Mendel Institute's crisis blew out at the time of the Tokyo congress, ISTS was strong and twin 
research was flourishing, so they were not greatly affected. Thanks to the endeavor of colleagues such as Walter Nance, Aldur Eriksson, Louis Keith, Robert Derom, Nick Martin, Elisabeth Bryan, Jaakko Kaprio, and many others, things continued more or less as before. The crisis had affected the Acta, and although scattered issues continued to be published for some time, it became clear that the Society was lacking a journal to support its activities. Through the good offices of Ian MacGillivray, the publisher Stockton Press, a division of MacMillan Press, agreed to the new enterprise and the new ISTS journal, Twin Research, began its publications in 1998, to be later moved to Australia with a new publisher, Australian Academic Press. Initially edited by Robert Derom and more recently by Nicholas G. Martin, with a widely representative Editorial Board, the journal has ensured the needed continuity and revitalisation of the previous line of action. The phoenix had risen again from its ashes.

The old Acta Geneticae Medicae et Gemellologiae born in 1952, restyled in the 1970s as AGMG/Twin Research, had thus not really come to an end. It survived, with its same subtitle as a title, with the same scope and the same reference scientific community, which gives it, and the entire field, continued viability, strength, and authority. Gedda would certainly be pleased with it. And so am I.

\section{References}

Allen, G., Eriksson, A. W., Fellman, J., Parisi, P., \& Vandenberg, S. G. (1992). Twinning and r/K reproductive strategy - A critique of Rushton's theory. Acta Geneticae Medicae et Gemellologiae, 41, 73-83.

Allen, G., \& Parisi, P. (1990). Trends in monozygotic and dizygotic twinning rates by maternal age and parity - Further analysis of Italian data, 1949-1985, and rediscussion of US data, 1964-1985. Acta Geneticae Medicae et Gemellologiae, 39, 317-328.

Boomsma, D., Busjahn, A., \& Peltorien, L. (2002). Classical twin studies and beyond. Nature Reviews, 3, 872-882.

Bulmer, M. G. (1959). The effect of parental age, parity, and duration of marriage on the twinning rate. Annals of Human Genetics, 23, 454-458.

Bulmer, M. G. (1970). The biology of twinning in man. Oxford: Clarendon Press.

Dahlberg, G. (1952). Die Tendenz zu Zwillingsgeburten. Acta Geneticae Medicae et Gemellologiae, 1, 80-88.

Duncan, J. M. (1865). On some laws of the production of twins, and on the comparative frequency of twinbearing in different pregnancies. Edinburgh Medical Journal, 10, 767-781, 928-929.

Eaves, L. J., Eysenck, H. J., \& Martin, N. G. (1989). Genes, culture and personality. An empirical approach. London-San Diego: Academic Press.
Eaves, L. J., Last, K., Martin, N. G., \& Jinks, J. L. (1977). A progressive approach to non-additivity and genotype-environmental covariance in the analysis of human differences. The British Journal of Mathematical and Statistical Psychology, 30, 1.

Eaves, L. J., Last, K. A., Young, P. A., \& Martin, N. G. (1978). Model-fitting approaches to the analysis of human behaviour. Heredity, 41, 249-320.

Eriksson, A. W., Eskola, H. J., \& Fellmann, J. O. (1976). Retrospective studies on the twinning rate in Scandinavia. Acta Geneticae Medicae et Gemellologiae, 25, 29-35.

Farber, S. L. (1981). Identical twins reared apart: A reanalysis. New York: Basic Books.

Fulker, D. W. (1978). Multivariate extensions of a biometrical model of twin data. In W. E. Nance, G. Allen, \& P. Parisi (Eds.), Twin research, Part A. New York: Alan R. Liss.

Fulker, D. W. (1982). Extensions of the classical twin method. In B. Bonné-Tamir (Ed.), Human genetics, Part A. New York: Alan R. Liss.

Galton, F. (1876). The history of twins, as a criterion of the relative powers of nature and nurture. Fraser's Magazine, Nov. 1875. (Reprinted, with revisions and additions). The Journal of the Royal Anthropological Institute, 5, 391.

Gedda, L. (1943). Il fenomeno dell'isoglutationemia gemellare e le sue applicazioni. Minerva Medica, 2, 29.

Gedda, L. (1951). Studio dei Gemelli, Orizzonte Medico, Roma. (1961 - English edition). Twins in History and Science. Springfield: Charles C. Thomas.

Gedda, L., \& Parisi, P. (1974). Twin studies, twin care, and international cooperation. Acta Geneticae Medicae et Gemellologiae, 23, 65.

Gedda, L., Parisi, P., \& Nance, W. E. (Eds.). (1981). Twin research 3: Part A, Twin biology and multiple pregnancy; Part B, Intelligence, personality, and development; Part C, Epidemiological and clinical studies (3 Vols.). New York: Alan R. Liss.

Gesell, A., \& Thompson, I. (1929). Learning and growth in identical infant twins: An experimental study by the method of so-twin control. ??Genet. Pyschol. Monographs, 6, 1.

Greulich, W. W. (1934). Heredity in human twinning. American Journal of Physical Anthropology, 19, 391-431.

Harris, J. R. (1913). Boanerges. Cambridge: University Press.

Holzinger, K. J. (1929). The relative effect of nature and nurture on twin differences. Journal of Educational Psychology, 20, 241.

Hrubec, Z. (1981). Methodological problems in matched-pair studies using twins. In L. Gedda, P. Parisi, \& W. E. Nance (Eds.), Twin research 3, Part C. New York: Alan R. Liss. 
James, W. H. (1972). Secular changes in dizygotic twinning rates. Journal of Biosocial Science, 4, 427-434.

Jinks, J. L., \& Fulker, D. W. (1970). Comparison of the biometrical, genetical, MAVA, and classical approaches to the analysis of human behavior. Psychological Bulletin, 73, 311-349.

Juel-Nielsen, N. (1964). Individual and environment. A psychiatric-psychological investigation of monozygotic twins reared apart. Acta Psychiatrica Scandinavica, 40(Suppl. 183), 1-158.

Keith, L. G., Papiernik, E., Keith, D. M., \& Luke, B. (1995). Multiple pregnancy. epidemiology, gestation and perinatal outcome. New York-London: Parthenon.

MacGillivray, I., Nylander, P. P. S., \& Corney, G. (Eds.). (1975). Human multiple reproduction. London: Saunders.

Martin, N. G., \& Eaves, L. J. (1977). The genetical analysis of covariance structure. Heredity, 38, 79-95.

Martin, N. G., Eaves, L. J., Kearsey, M. J., \& Davies, P. (1978). The power of the classical twin study. Heredity, 40, 97-116.

Nance, W. E. (1976). Genetic studies of the offspring of identical twins: A model for the analysis of quantitative inheritance in man. Acta Geneticae Medicae et Gemellologiae, 25, 103-113.

Nance, W. E., Allen, G., \& Parisi, P. (Eds.). (1978). Twin research. Part A, Psychology and methodology; Part $B$, Biology and epidemiology; Part C, Clinical studies (3 Vols.). New York: Alan R. Liss.

Nance, W. E., \& Parisi, P. (1987). New approaches in twin research. Applications in genetic epidemiology. In F. Vogel \& K. Sperling (Eds.), Human Genetics. Berlin: Springer.

Newman, H. H., Freeman, F. N., \& Holzinger, K. J. (1937). Twins: A study of heredity and environment. Chicago: University of Chicago Press.

Parisi, P. (Ed.). (1970). Advances in twin studies. Acta Geneticae Medicae et Gemellologiae, 19, 1-2.

Parisi, P. (1989). Biology of twinning. In E. Meisami \& P.S. Timiras (Eds.), Handbook of human growth and developmental biology (pp. 207-228). Boca Raton, FL: CRC Press.

Parisi, P. (1995). The twin method. In L. G. Keith, E. Papiernik, D. M. Keith, \& B. Luke (Eds.), Multiple pregnancy - Epidemiology, gestation and perinatal outcome (pp. 9-20). Carnforth, Lancs.: Parthenon Publishing.

Parisi, P. (1997). Twins and creation. In A. Montuori (Ed.), Unusual associates (pp. 359-376). Cresskill, NJ: Hampton Press

Parisi, P. (2000). Luigi Gedda 1902-2000. Twin Research, 3, 344-347.

Parisi, P., \& Caperna, G. (1982). Twinning rates, fertility, and industrialization - A secular study. In B. BonnéTamir (Ed.), Human genetics, A: The unfolding genome (pp. 375-394). New York: Alan R. Liss.

Parisi, P., Gatti M., Prinzi, G., \& Caperna, G. (1983). Familial incidence of twinning. Nature, 304, 626-628.

Plomin, R., De Fries, J. C., \& Mc Clearn, G. E. (1990). Behavioral genetics - A primer (2nd ed.). New York: Freeman.

Price, B. (1950). Primary biases in twin studies. American Journal of Human Genetics, 2, 293.

Rende, R. D., Plomin, R., \& Vandenberg, S. G. (1990). Who discovered the twin method? Behavior Genetics, 20, 277-285.

Risch, N., \& Zhang, H. (1995). Extreme discordant sib pairs for mapping quantitative trait loci in humans. Science, 268(5217), 1584-1589.

Shields, J. (1962). Monozygotic twins brought up apart and brought up together. London: Oxford University Press.

Spemann, H. (1938). Embryonic development and induction. New Haven: Yale University Press.

Weinberg, W. (1909). Die anlage zur mehrlingsgeburt beim menschen und ihre vererbung. Archiv fuer Rassenhygiene und gesamte Biologie, 6, 322-329, 470-482, 609-630.

Wilson, R. S. (1978). Synchronies in mental development: An epigenetic perspective. Science, 202, 939-948.

Wilson, R. S. (1979). Twin growth: Initial deficit, recovery, and trends in concordance from birth to nine years. Annals of Human Biology, 6, 205-220.

Wyshak, G., \& White, C. (1965). Genealogical study of human twinning. American Journal of Public Health, 55, 1586-1593.

Zazzo, R. (1984). Le paradoxe des jumeaux. Paris: Stock/Laurence Pernoud.

Zazzo, R. (1986) Les jumeaux, le couple et la personne (2nd ed.). Paris: Presses Universitaires de France. 